\title{
Fresh figs (Ficus carica L.): pomological characteristics, nutritional value, and phytochemical properties
}

\author{
S. Mahmoudi ${ }^{1,2}$, M. Khali ${ }^{2}$, A. Benkhaled ${ }^{3}$, I. Boucetta ${ }^{1}$, Y. Dahmani ${ }^{3}$, Z. Attallah ${ }^{3}$ and S. Belbraouet ${ }^{4}$ \\ ${ }^{1}$ Department of Agronomic Sciences, University “Med Boudiaf”, M’sila, Algeria \\ ${ }^{2}$ Department of Food Sciences, University "Saâd Dahleb", Blida, Algeria \\ ${ }^{3}$ Department of Microbiology and Biochemistry, University "Med Boudiaf”, M’sila, Algeria \\ ${ }^{4}$ Faculty of Health Sciences and Community Services, University of Moncton, Canada
}

\section{Summary}

Ficus carica L. (Moraceae) is a wild spread tree including more than 600 cultivars with different phenotypic characteristics. Their fruits are a good natural source of nutrients, minerals, and phytochemicals, which may improve human health. The pomological characteristics of nine Algerian cultivars of fresh figs were determined using descriptors resulting from the IPGRI and CIHEAM list. The consumer test was carried out using an in-store consumer test. The proximal components (dry matter, ash, titratable acidity, crude protein (Kjeldahl), ascorbic acid, and carbohydrates) were estimated using the AFNOR and Dubois methods. Minerals ( $\mathrm{Ca}, \mathrm{K}$, and $\mathrm{Na}$ ) were analyzed using a flame spectrophotometer. Phosphorus, phenolic, flavonoid, anthocyanin, and condensed tannin concentrations were quantified by UV-spectrophotometer. The antioxidant capacity was evaluated using the 2, 2-diphenyl-1-picrylhydrazyl (DPPH) radical scavenging assay. The pomological results obtained made it possible to discriminate between the different fig cultivars. Skin color results indicate two groups (light skin and dark skin groups). The consumers preferred 'Boughandjo', 'Bither', and 'Bakkor Biadh', with high percentages of acceptance $(68.75,70.31$ and $75 \%$ ). Figs are a good source of carbohydrates (especially 'Safra' pulp [26.02 $\pm 0.63 \mathrm{~g}^{100 \mathrm{~g}^{-1} \text { Fresh }}$ weight]), vitamin $C\left(10.67 \pm 0.31 \mathrm{mg} 100 \mathrm{~g}^{-1}\right.$ Fresh weight for 'Onk Elhamam' peel), and potassium and

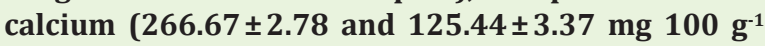
Fresh weight for 'Bakkor Khal' peel, respectively). In the majority of the tested cultivars, peels exhibited higher phenolic (1.63 vs. $1.11 \mathrm{mg}$ gallic acid equivalents $\mathrm{g}^{-1}$ Fresh weight), flavonoid (147.76 vs. $83.82 \mu \mathrm{g}$ quercetin equivalents $\mathrm{g}^{-1}$ Fresh weight), anthocyanin (64.82 vs. $41.72 \mu$ g cyanidin-3-rutinoside equivalents $\mathrm{g}^{-1}$ Fresh weight) and condensed tannin ( $6.08 \mathrm{vs.}$ $2,06 \mu$ catechol equivalents $\mathrm{g}^{-1}$ Fresh weight) levels and antioxidant activities (18.91 vs. $29.51 \mathrm{mg} \mathrm{mL}^{-1}$ ) than pulps. Peels of dark cultivars showed higher phytochemical and antioxidant properties than those of light cultivars. Antioxidant activity was correlated with total phenolic and condensed tannin concentrations ( $r=0.521$ and 0.659$)$. The pomological characterization and consumer tests reported here are important for allowing farmers to judge about the potential of the tested cultivars and could be helpful during fig breeding and cultivar selection. Based on their diversity, tastes, nutritional and phytochemical

\section{Significance of this study}

What is already known on this subject?

- The diversity of figs, their nutritional contribution in the diet, and their impact on human health has been studied for many cultivars around the world. Nevertheless, there are more than 600 fig tree cultivars. Here we describe novel cultivars from the Mediterranean region. We highlighted the nutritional value and phytochemical characteristics of fig peel because the majority of consumers tend to peel figs before consumption.

What are the new findings?

- By pomological characterization, we were able to discriminate between the studied cultivars. Also, using a sensory test, we found that consumers prefer some unknown and underutilized cultivars ('Bither', 'Boughandjo', 'Zarrouk', and 'Hamra'). Fig peel, especially of dark skin cultivars, is an important source of minerals such as calcium and potassium and of phytochemicals, which have a positive impact on human health.

What is the expected impact on horticulture?

- Our data will likely help farmers to select the most appropriate cultivars for fresh consumption, especially those of higher yield (e.g., 'Boughandjo') and precocious types (e.g., 'Bither'). Our data will also help farmers identify those cultivars with the greatest nutritional value and phytochemical properties.

attributes, we recommend figs (especially those with dark skin) as healthy food.

\section{Keywords}

consumer test, cultivars, descriptors, minerals, Moraceae, phenolics, proximal components

\section{Introduction}

The Common Fig (Ficus carica L.) is a tree native to southwest Asia and the eastern Mediterranean region, belonging to the botanical family Moraceae (Duenas et al., 2008). The fig tree is cultivated for its fruit in warm and dry climates, and the dried fruit has been a familiar food for humans since 3000 BC (Hatano et al., 2008). 
In the northern Mediterranean region, fig trees produce one or two crops per year, depending on the cultivar (Veberic et al., 2008). Annually, over 1 million tons of fresh figs are harvested from 308,460 hectares worldwide. Mediterranean countries are the main fig producers. Algeria produces $12.54 \%$ of the total global fig crop (FAO, 2016).

In Algeria, fig trees are grown all over the country (coastal, steppe and Saharan areas) because of its pedoclimatic adaptation, nutritional and therapeutic values, and its place in the culinary practices of the Algerians. Algerian fig production is concentrated primarily in the Kabyle mountainous area (Bejaia and Tizi-Ouzou account for $27 \%$ and $13 \%$ of total national production respectively) (MADR, 2012).

These fruits have forms, colors, tastes, technological and therapeutic properties that differ between varieties and are generally named according to their shape, color, and the region in which it is most cultivated. In 1850, more than $70 \mathrm{fig}$ varieties were introduced to Algeria. However, these were not adopted by the local farmers, who continued to grow the fig trees that were familiar to them. Recently, the Technical Institute of Fruit-bearing Arboriculture in Algeria described 40 varieties, including comestible varieties and caprifig types (Chouaki, 2006; Meziant et al., 2015). However, the number of cultivars grown in Algeria is likely to be much greater than these 40 varieties.

Figs are an excellent source of minerals, vitamins, and dietary fiber; they are fat and cholesterol-free and contain a high number of amino acids (Slavin, 2006; Solomon et al., 2006). Similarly to other fruit species, figs contain sugars and organic acids that influence their quality (Veberic et al., 2008).

Several studies have been made on the phenolic compounds of figs such as phenolic acids, flavonoids, and anthocyanins with antioxidant capacity have been isolated from fig fruits (Duenas et al., 2008; Veberic et al., 2008; Çaliskan and Polat, 2011). Antioxidant compounds scavenge free radicals, thus inhibiting the oxidative mechanisms that lead to degenerative illnesses (Oliveira et al., 2009).

Here we aimed to characterize the genetic diversity of some fig genotypes grown in Algeria using pomological descriptors, and to evaluate their consumer acceptance. We also aimed to highlight the varietal influences on the nutritional value, the phytochemical composition, and the antioxidant activities of pulps and peels of those fig cultivars. This study is a contribution to the knowledge and the valorization of some dark and light, fresh figs. To our knowledge, this is the first such work on these cultivars.

\section{Materials and methods}

\section{Standards and reagents}

All standards and reagents used in this study were of analytical grade and purchased from Merck Chemicals, Sigma-Aldrich (Germany), Cheminova (France), Fluka or Rectapur.

\section{Plant materials}

Local fresh and ripe figs (Ficus carica L.) of nine cultivars ('Bakkor Biadh', 'Bakkor Khal', 'Bidha', 'Bither', 'Boughandjo', 'Hamra', 'Onk Elhamam', 'Safra', and 'Zarrouk') (Supplementary Figure S1) were collected during August and September 2015 and 2016 from an orchard in Lakhdaria (the mountain), Department of Bouira (Northeast of Algeria). For the pomological assessment, 25 fruits were randomly taken from three to five trees for each cultivar (age: 15 to 20 years) in each year and were immediately transferred to the laboratory and analyzed. The fruit pulp (500 g) and peel (500 g) of each cultivar (production of 2016) were separated, blended and frozen at $-18^{\circ} \mathrm{C}$ until used for nutritional and phytochemical analyses.

\section{Pomological assessment}

Twenty-eight qualitative and quantitative pomological descriptors resulting from the IPGRI and CIHEAM (2003) list were used to discriminate between the studied fig cultivars. Qualitative descriptors concerned: beginning of maturation, harvest period, production type, fruit internal and external color, fruit skin cracks, peeling of skin, fruit shape [index (width/length) = I], fruit shape according to the location of the maximum width, pulp juiciness and flavor, drop at the eye, color of liquid drop at the eye, fruit lenticels quantity, lenticels color, and fruit cavity. The quantitative descriptors comprised: fruit weight, pulp weight, peel weight, fruit length, fruit width, fruit skin thickness, neck and stalk length, ostiole width, and titratable acidity.

\section{Fig skin color}

Fig skin color measurements were made using a portable tristimulus color analyzer (Konica MINOLTA CM-2600 d) and expressed in International Commission on Illumination (CIE) $\mathrm{L}^{*}, \mathrm{C}^{*}, \mathrm{~h}^{*}, \mathrm{a}^{*}$ and $\mathrm{b}^{*}$. The colorimeter was calibrated using the manufacturer's standard reference black and white calibration tiles. Skin color was measured on four fresh fruits by cultivar and at three random positions per fruit (Crisosto et al., 2010; Çaliskan and Polat, 2011).

TABLE S1. Correlation coefficients (r) of phytochemical, color and antioxidant parameters of fig cultivars.

\begin{tabular}{|c|c|c|c|c|c|c|c|c|c|}
\hline Parameters & $Y$ & PC & FC & $A C$ & CTC & IC50 & $L^{*}$ & $\mathrm{C}^{*}$ & $h^{*}$ \\
\hline$Y$ & 1.000 & 0.321 & 0.145 & 0.351 & 0.176 & -0.207 & 0.266 & 0.291 & 0.250 \\
\hline PC & 0.321 & 1.000 & 0.227 & 0.364 & 0.779 & -0.521 & 0.386 & 0.444 & -0.084 \\
\hline $\mathrm{FC}$ & 0.145 & 0.227 & 1.000 & 0.656 & 0.455 & -0.275 & 0.197 & 0.104 & 0.109 \\
\hline$A C$ & 0.351 & 0.364 & $0.656^{* *}$ & 1.000 & 0.519 & -0.345 & 0.595 & 0.433 & -0.154 \\
\hline CTC & 0.176 & $0.779^{* * *}$ & 0.455 & $0.519^{*}$ & 1.000 & -0.659 & 0.347 & 0.348 & 0.144 \\
\hline IC50 & -0.207 & $-0.521^{*}$ & -0.275 & -0.345 & $-0.659^{* *}$ & 1.000 & 0.071 & 0.097 & 0.055 \\
\hline$L^{*}$ & 0.266 & 0.386 & 0.197 & 0.595 & 0.347 & 0.071 & 1.000 & 0.979 & -0.138 \\
\hline$C^{*}$ & 0.291 & 0.444 & 0.104 & 0.433 & 0.348 & 0.097 & $0.979^{* * *}$ & 1.000 & -0.124 \\
\hline$h^{*}$ & 0.250 & -0.084 & 0.109 & -0.154 & 0.144 & 0.055 & -0.138 & -0.124 & 1.000 \\
\hline
\end{tabular}

Abbreviations: Y: yield, PC: polyphenol concentration, FC: flavonoid concentration, AC: anthocyanins concentration: CTC: condensed tannin concentration. $L^{*}$ : luminosity, $C^{*}$ : Chroma, $h^{*}$ : hue ${ }^{\circ} .{ }^{*} p<0.05,{ }^{* *} p<0.01,{ }^{* * *} p<0.001$. 


\section{Consumer test}

The consumer acceptance evaluation of the nine fresh fig cultivars was carried out using an in-store consumer test, as described by Crisosto et al. (2010). Sixty-four consumers (40 males and 24 females) with an interval age ranging from 16 to 55 years were surveyed at a fruit and vegetable store in August 2016.

For each sample, the consumers were asked to taste one half-fig and then to indicate, all things considered, which statement best describes how they feel about the sample on a 9 -point hedonic scale $(1=$ dislike extremely to $9=$ like extremely). Consumer acceptance was measured as both degrees of liking (1 to 9) and percentage of acceptance.

\section{Nutritional analysis}

Nutritional analyses were carried out on $500 \mathrm{~g}$ of peel and pulp of each cultivar resulting from the production of 2016. Dry matter was determined by weighing the fresh sample before and after oven drying at $103 \pm 2^{\circ} \mathrm{C}$ for $16 \mathrm{~h}$ and ash by muffle incineration at $550^{\circ} \mathrm{C}$ (AFNOR, 1982), titratable acidity content was analyzed by titration with $0.1 \mathrm{~N}$ $\mathrm{NaOH}$ up to pH 8.1 and expressed as g citric acid $100 \mathrm{~g}^{-1} \mathrm{FW}$ (Sen et al., 2008). Total carbohydrates were estimated by Dubois method (Dubois et al., 1956) and crude protein by Kjeldahl method (AFNOR NEV 03-050, 1970). The content of ascorbic acid was determined as described by Tareen et al. (2015). The minerals including calcium (Ca), potassium (K) and sodium $(\mathrm{Na})$ were analyzed by a flame spectrophotometer. Phosphorus concentration was estimated by the phospho-vanado-molybdic method described by Youshida et al. (1976).

\section{Extraction}

For the phytochemical analyses, $10 \mathrm{~g}$ of fruit materials were macerated in $100 \mathrm{~mL}$ pure methanol for $24 \mathrm{~h}$ at room temperature. Extracts were filtered through filter paper $n^{\circ} 1$ and solvent was evaporated under reduced pressure at $40^{\circ} \mathrm{C}$ using a rotary vacuum evaporator (Büchi). The residues were kept under refrigerated conditions until used. The yield (percentage) of evaporated dried extracts was calculated as $100 \mathrm{EW} / \mathrm{SW}$, where EW is extracted weight after evaporation of solvent and SW is sample weight.

\section{Phytochemical analyses}

Total polyphenols were measured by the Folin-Ciocalteu method: $200 \mu \mathrm{L}$ of each extract was mixed successively with $1 \mathrm{ml}$ of Folin-Ciocalteu reagent $(10 \% \mathrm{v} / \mathrm{v})$ and $800 \mu \mathrm{L}$ of sodium carbonate solution $\left(\mathrm{Na}_{2} \mathrm{CO}_{3}\right)$ at $7.5 \%(\mathrm{w} / \mathrm{v})$. The mixture was incubated for $10 \mathrm{~min}$ in a bath at $40^{\circ} \mathrm{C}$., and absorbencies were measured at $760 \mathrm{~nm}$. Total polyphenols were expressed as milligrams gallic acid equivalents per gram of fresh weight (mg GAE g-1 FW) using a gallic acid calibration curve (Fu et al., 2011). To determine flavonoid concentration, equal volumes of the extract and aluminum trichloride solution at $2 \%$ $(\mathrm{w} / \mathrm{v})$ were mixed. After $10 \mathrm{~min}$ of incubation at room temperature, the absorbencies were read at $430 \mathrm{~nm}$. Total flavonoid concentration was expressed as micrograms quercetin equivalents per gram of fresh weight ( $\left.\mu \mathrm{g} \mathrm{QE}^{-1} \mathrm{FW}\right)$ using a quercetin calibration curve (Koolen et al., 2013).

Total monomeric anthocyanin pigment concentrations were measured using the AOAC Official Method 2005.02, as described by Lee et al. (2005): absorbencies of test portions diluted with $\mathrm{pH} 1.0$ buffer, and $\mathrm{pH} 4.5$ buffer were determined at both 520 and $700 \mathrm{~nm}$. Anthocyanin pigment concentration was expressed as micrograms of cyanidin-3-ruti- noside equivalents $\mathrm{g}^{-1} \mathrm{FW}$ and calculated as follows: Anthocyanin pigment $=A \times M W \times D F \times 1000 / \varepsilon \times l$. Where $A=(A 520 \mathrm{~nm}$ - A 700 nm) pH 1.0 - (A 520 nm - A 700 nm) pH 4.5; MW (molecular weight $)=595.2\left(\mathrm{~g} \mathrm{~mol}^{-1}\right)$ for cyanidin-3-rutinoside; $\mathrm{DF}=$ dilution factor; $\mathrm{l}=$ path-length $(\mathrm{cm}) ; \varepsilon=28800$ molar extinction coefficient $\left(\mathrm{L} \mathrm{mol}^{-1} \mathrm{~cm}^{-1}\right)$ and $10^{3}=$ factor for conversion from $\mathrm{g}$ to $\mathrm{mg}$.

Condensed tannins were quantified using the spectrophotometric method of vanillin in the acid solution described by Ba et al. (2010). A proportion $(200 \mu \mathrm{L})$ of each extract was mixed with $1 \mathrm{~mL}$ of vanillin reagent (a mixture in an equal volume of $\mathrm{HCl}$ at $8 \%[\mathrm{v} / \mathrm{v}]$ in methanol and vanillin solution at $4 \%[\mathrm{w} / \mathrm{v}]$ in methanol). The mixture was shaken, incubated at room temperature for $20 \mathrm{~min}$, and the absorbance was determined at $500 \mathrm{~nm}$ using a spectrophotometer. The condensed tannin concentration was expressed as micrograms of catechol equivalents per gram of fresh weight

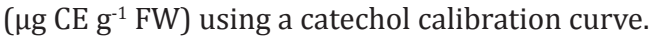

Antioxidant activity was determined according to Koh et al. (2012). A proportion $(0.3 \mathrm{~mL})$ of each extract at different concentrations was mixed with $2.7 \mathrm{~mL}$ of DPPH reagent $\left(6 \times 10^{-5} \mathrm{~mol} \mathrm{~L}^{-1}\right)$. The mixture was incubated in darkness at room temperature for $60 \mathrm{~min}$, and the absorbance was measured at $517 \mathrm{~nm}$. Antioxidant activity (\%) was calculated as: antioxidant activity $=\left(\left(\mathrm{A}_{\text {control }}-\mathrm{A}_{\text {sample }}\right) / \mathrm{A}_{\text {control }}\right) \times 100$, where $A_{\text {control }}$ is the absorbance of the DPPH solution without extract and $A_{\text {sample }}$ is the absorbance of the DPPH solution with extract (various concentrations).

\section{Statistical analysis}

Results were shown as mean \pm SEM. Statistical significance at $\mathrm{p}<0.05$ was determined by ANOVA (one- and twoway) followed by Tukey's multiple comparison tests using GraphPad Prism 6 statistics program.

\section{Results and discussion}

\section{Pomological assessment}

The qualitative and quantitative pomological characteristics are presented in Tables 1 and 2, respectively. The cultivars 'Bakkor Biadh', 'Bither' and 'Bakkor Khal' are biferous types bearing two crops by year, whereas the others are uniferous types producing the fruits of the second crop in August and September. Except 'Bakkor Biadh' and 'Bither', which were categorized as very early (fruit ripening started at the end of July) with a very short harvesting period ( $<15$ days), the other varieties produce in mid-season (fruit ripening started in the middle of August) and mostly have a short harvesting period (15-20 days). Periods of fruit ripening and of harvestings of the studied cultivars varied from year to year, depending on the climate conditions. Generally, in hot summers, fig ripening starts earlier and the period of harvesting is shorter than in cool summers.

In all biferous cultivars and 'Hamra', no ostiole drop was observed. For the other cultivars, the color of the ostiole drop varied from transparent to red.

Easy skin peeling is an important character for consumer acceptance (especially for the cultivars that have a thick skin, such as 'Bakkor Biadh' and 'Onk Elhamam') because consumers tend to peel figs before eating. This result is in agreement with Ilgin (1995). Concerning the skin cracks, all of the cultivars presented skin cracks, except 'Bakkor Biadh' and 'Bither'. Skin cracks influence consumer acceptance because consumers think that this parameter indicates the degree of fruit ripening. 

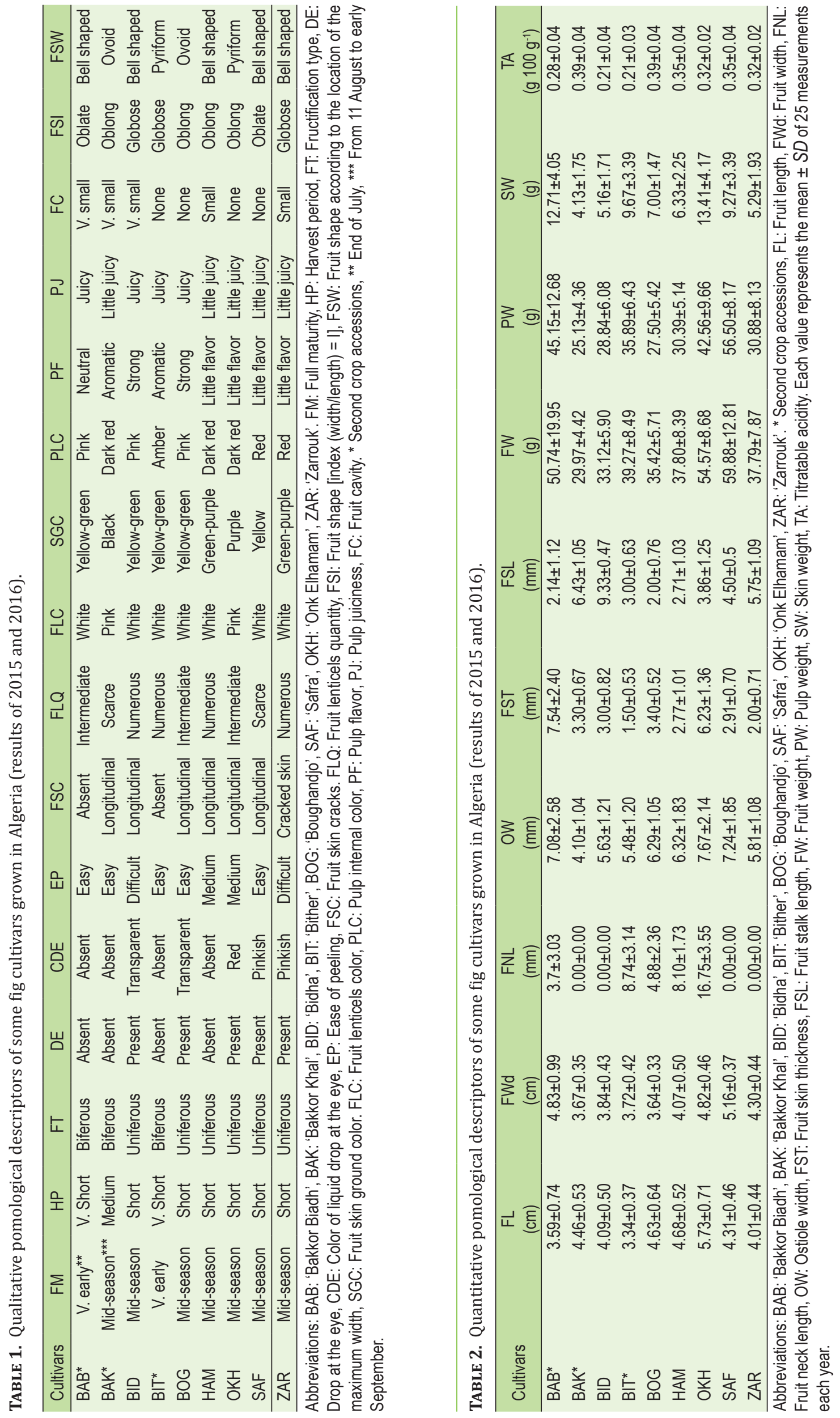
The fruit skin color of the fig cultivars was yellow-green, green-purple, yellow, purple and black. Fruit pulp color was brilliant, varying between amber, pink, red and dark-red. Regarding the fruit lenticels quantity, it was scarce to numerous, and their colors ranged between white and pink. Skin color is an essential parameter, which affects consumer perception of fresh figs and used to determine their ripening period.

The figs tested were neutral to strongly aromatic and little juicy to juicy. The fruit shape [index (width/length) = I] was globose, oblong or oblate, whereas it is pyriform, ovoid or bell-shaped according to the localization of the maximum width.

Fruit length and width varied from 3.34 to $5.73 \mathrm{~cm}$ and from 3.64 to $5.16 \mathrm{~cm}$, and ostiole width ranged between 4.1 and $7.7 \mathrm{~mm}$ (Table 2). The ostiole width values in our study are much higher than those (1.1 to $4.9 \mathrm{~mm}$ ) reported by Çaliskan and Polat (2008). It is important to note that a large ostiole in the fig is an undesirable characteristic. The smaller the ostiole width, the better the fruit can be stored and protected from infectious agents (Trad et al., 2012). Neck length, skin thickness, stalk length, pulp weight, and skin weight varied among the cultivars. The fruit of the variety 'Onk Elhamam' is the longest $(5.73 \mathrm{~cm})$ whereas that of 'Safra' is the broadest ( $5.16 \mathrm{~cm})$. 'Bakkor Khal', 'Safra', 'Bidha', and 'Zarrouk' presented no neck, and 'Onk Elhamam' had the longest neck (16.75 mm). The 'Onk Elhamam' cultivar takes its name of the length of its neck. The presence of a neck in figs facilitates picking the fruit from the tree, and is thus associated with easier harvesting (Trad et al., 2012).

In general, all studied cultivars exhibited light to medium fruit weight (29.97 to $59.88 \mathrm{~g}$ ). Additionally, the titratable acidity of figs varied between 0.21 and $0.39 \%$ citric acid equivalents. In similar studies of figs, the fruit weights varied from 35.6 to $55.6 \mathrm{~g}$ (Crisosto et al., 2010) and 22.2 to $52.5 \mathrm{~g}$ (Çaliskan and Polat, 2008). Those authors recorded an interval of acidity that ranged from 0.22 to $0.42 \%$ and from 0.09 to $0.26 \%$. Acidity decreases with the fig maturity and the fruit sizes differ according to the genotype and the tree age (Çaliskan and Polat, 2008; Crisosto et al., 2010).

\section{Fig skin color}

Our results indicate variability in fig skin color of the tested cultivars from the mountainous region of Lakhdaria. Fig skin colors varied from purple to black for the dark skin group ('Bakkor Khal', 'Hamra', 'Onk Elhamam' and 'Zarrouk') and from yellow to green-yellow for the light skin group ('Bakkor Biadh', 'Bidha', 'Bither', 'Boughandjo' and 'Safra')
(Table 3).

The luminosity $\left(\mathrm{L}^{*}\right)$ and chroma $\left(\mathrm{C}^{*}\right)$ values of the light skin group were higher than those of dark skin group. Whereas the dark skin group had a* positive values (mean: 6.52) and the light skin group had $\mathrm{a}^{*}$ negative values (mean: -4.21). $\mathrm{Hue}^{\circ}\left(\mathrm{h}^{*}\right)$ values ranged from 90.65 to 98.01 for the light skin group (range of the green-yellow colors) and from 20.14 to 50.74 (range of red-yellow colors) and 280.2 (range of blue colors) for the dark skin group. The $b^{*}$ values varied from $-2.63 \pm 1.03$ to $5.79 \pm 3.08$ for the dark skin group and from $32.07 \pm 2.59$ to $55.00 \pm 2.14$ for the light skin group (Table 3 ).

The higher values of luminosity and chroma of the green cultivars denote lighter and more intense colors (Crisosto et al., 2010). Chroma is one of the most important characteristics used to define the quality of food and has a decisive influence on consumer's acceptance (Hendry et al., 1996).

\section{Consumer test}

According to the results reported in Table 4, the consumers slightly preferred 'Boughandjo', 'Bither', 'Bakkor Biadh', 'Onk Elhamam', and 'Hamra', with a high percentage of acceptance for the biferous varieties 'Bakkor Biadh' (75\%) and 'Bither' (70.31\%) than the other tested varieties. Consumers probably prefer 'Bakkor Biadh' because the fruit of this cultivar is less sweet than the others; its flesh is juicy, its skin is thick but easy to peel, and it contains a few grains.

The percentage of consumers who neither liked nor disliked the various varieties of figs $(18.23 \%$ on average) is 3.23 -times less than the consumers that liked the different cultivars (58.85\% on average).

In this study, it was observed that the 'Safra' and 'Bidha' cultivars are the less preferred cultivars (42.19 and 48.44\%) (Table 4). The 'Bidha' variety is very sweet and tasty but its skin is very rigid, rough and difficult to peel, and it contains a lot of grains; the 'Safra' variety has an attractive shape and color, but it is little juicy and has little flavor. Although the 'Bidha' cultivar is less appreciated for fresh consumption, it is very suitable for drying thanks to its fine skin, its high degree of sweetness, and its attractive shape and color after drying.

The majority of consumers tend to peel their fig at least until halfway, and for them, ease of peeling, pulp flavor, juiciness, sweetness, and acidity are the most important factors which determine their acceptance. Crisosto et al. (2010) reported that maturity stage and flavor perception had a significant effect on consumer acceptance. Nevertheless, preferences in flavor change according to the demand of consum-

TABLE 3. Chromaticity values $\left(L^{*}, C^{*}, h^{*}, a^{*}\right.$ and $\left.b^{*}\right)$ of fig skin of nine cultivars (results of 2016).

\begin{tabular}{|c|c|c|c|c|c|c|}
\hline Cultivars & Color & $L^{*}$ & $C^{*}$ & $h^{*}$ & $a^{*}$ & $b^{*}$ \\
\hline Bakkor Biadh* & Green-yellow & $67.52 \pm 4.01$ & $46.34 \pm 3.38$ & $96.22 \pm 3.18$ & $-6.13 \pm 1.89$ & $43.27 \pm 3.73$ \\
\hline Bakkor Khal* & Black & $32.03 \pm 3.09$ & $3.00 \pm 0.94$ & $280.20 \pm 13.22$ & $0.69 \pm 0.26$ & $-2.63 \pm 1.03$ \\
\hline Bidha & Green-yellow & $65.90 \pm 2.15$ & $48.23 \pm 2.90$ & $96.14 \pm 2.34$ & $-6.15 \pm 1.45$ & $47.98 \pm 3.02$ \\
\hline Bither ${ }^{*}$ & Green-yellow & $63.55 \pm 2.68$ & $47.33 \pm 2.55$ & $97.70 \pm 3.59$ & $-5.15 \pm 2.78$ & $45.83 \pm 2.78$ \\
\hline Boughandjo & Green-yellow & $62.37 \pm 1.21$ & $31.83 \pm 2.33$ & $98.01 \pm 4.84$ & $-5.38 \pm 1.19$ & $32.07 \pm 2.59$ \\
\hline Hamra & Green-purple & $37.17 \pm 3.11$ & $8.95 \pm 2.28$ & $44.37 \pm 24.44$ & $6.86 \pm 0.66$ & $-0.49 \pm 1.01$ \\
\hline Onk Elhamam & Purple & $38.06 \pm 1.01$ & $9.45 \pm 1.15$ & $20.14 \pm 5.34$ & $11.22 \pm 2.49$ & $1.74 \pm 1.71$ \\
\hline Safra & Yellow & $79.20 \pm 4.48$ & $54.70 \pm 2.14$ & $90.65 \pm 2.01$ & $1.78 \pm 1.82$ & $55.00 \pm 2.14$ \\
\hline Zarrouk & Green-purple & $38.97 \pm 2.02$ & $10.26 \pm 1.53$ & $50.74 \pm 25.64$ & $7.31 \pm 2.63$ & $5.79 \pm 3.08$ \\
\hline
\end{tabular}

Abbreviations: *: Second crop accessions, $L^{*}$ : luminosity (ranging from darkness to lightness), $C^{*}$ : Chroma (indicating intensity or saturation of the color), $h^{*}$ : hue (Angle that indicates the pure spectrum color), $a^{*}$ : negative values indicate green color and positive values indicate red color. $b^{*}$ : negative values indicate blue color and positive values indicate yellow color. Each value represents the mean $\pm S E M$ of 12 measurements. 
TABLE 4. Consumer acceptance of nine local fresh fig cultivars (results of 2016).

\begin{tabular}{lcccc}
\hline Cultivars & $\begin{array}{c}\text { Note } \\
(1-9)^{\mathrm{s}}\end{array}$ & $\begin{array}{c}\text { Dislike } \\
(\%)\end{array}$ & $\begin{array}{c}\text { Neither like nor dislike } \\
(\%)\end{array}$ & $\begin{array}{c}\text { Acceptance } \\
(\%)\end{array}$ \\
\hline Bakkor Biadh $^{*}$ & $6.33^{\mathrm{h}}$ & $10.94^{\mathrm{a}}$ & $14.06^{\mathrm{c}}$ & $75.00^{\mathrm{f}}$ \\
Bakkor Khal $^{*}$ & $5.58^{\mathrm{b}}$ & $20.31^{\mathrm{b}}$ & $28.13^{\mathrm{b}}$ & $51.56^{\mathrm{b}}$ \\
Bidha $^{\mathrm{b}}$ & $5.29^{\mathrm{e}}$ & $34.38^{\mathrm{e}}$ & $17.19^{\mathrm{ace}}$ & $48.44^{\mathrm{c}}$ \\
Bither $^{*}$ & $10.94^{\mathrm{a}}$ & $18.75^{\mathrm{a}}$ & $70.31^{\mathrm{a}}$ \\
Boughandjo & $6.56^{\mathrm{a}}$ & $10.94^{\mathrm{a}}$ & $20.31^{\mathrm{a}}$ & $68.75^{\mathrm{a}}$ \\
Hamra & $6.61^{\mathrm{a}}$ & $26.56^{\mathrm{c}}$ & $12.50^{\text {cf }}$ & $60.94^{\mathrm{e}}$ \\
Onk Elhamam & $6.01^{\mathrm{g}}$ & $17.19^{\mathrm{b}}$ & $20.31^{\mathrm{a}}$ & $62.50^{\mathrm{e}}$ \\
Safra & $6.11^{\mathrm{f}}$ & $46.88^{\mathrm{d}}$ & $10.94^{\mathrm{cf}}$ & $42.19^{\mathrm{d}}$ \\
Zarrouk & $4.95^{\mathrm{d}}$ & $28.13^{\mathrm{c}}$ & $21.88^{\mathrm{ad}}$ & $50.00^{\mathrm{bc}}$ \\
\hline
\end{tabular}

* Second crop accessions, ${ }^{\text {s }}$ Degree of liking: 1 = dislike extremely, 2 = dislike very much, 3 = dislike moderately, $4=$ dislike slightly, $5=$ neither like

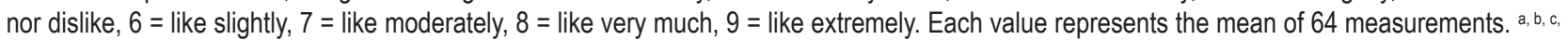
$\mathrm{d}, \mathrm{e}, \mathrm{f}, \mathrm{g}, \mathrm{h}$ Mean values in the same column with different letters are significantly different at $p<0.05$ by mean of the Tukey's multiple comparison test.

ers. Cultivars with high sugar concentrations are in demand in domestic and Middle Eastern markets, whereas cultivars low in sugar are requested in European markets (Polat and Çaliskan, 2008).

\section{Nutritional analysis}

The physical and chemical characteristics of the fig pulps and peels are shown in Table 5 . The fig pulps were more acid $(\mathrm{p}<0.05)$ than their peels $(0.4 \pm 0.11$ and $0.2 \pm 0.05 \%)$. This is in agreement with Oliveira et al. (2009) who reported that fig peels exhibited lower contents of organic acids than pulps. Organic acids contained in fruit are an important factor of its flavor development.

The pulp is juicier than the peel, having mean dry matter contents of $23.97 \pm 4.53 \%$ and $26.13 \pm 3.74 \%$ respectively. The 'Bakkor Biadh' and 'Bither' cultivars are the most humid.
Fruit dry matter (DM) has emerged in recent years as another indicator of internal quality. DM is essentially a reflection of fruit carbohydrate content (Travers, 2013). The percentage of total ashes varied significantly $(\mathrm{p}<0.05)$ according to the fruit part and cultivar.

Minerals are micronutrients involved in many biochemical processes, and a suitable intake of these minerals is essential for the prevention of diseases related to minerals insufficiency (Leterme et al., 2006). Potassium was the most abundant mineral in the figs, which is in agreement with Sadia et al. (2014). Of the tested cultivars, the peel and pulp of 'Bakkor Khal' had the highest sources of potassium $\left(266.7 \pm 2.8\right.$ and $\left.254.2 \pm 6.9 \mathrm{mg} 100 \mathrm{~g}^{-1} \mathrm{FW}\right)$. Potassium is one of the important nutrients for controlling human blood pressure, therefore fig fruits were recommended for hypertension in previous studies (Sadia et al., 2014).

TABLE 5. Physical and chemical characteristics of fig pulps and peels (results of 2016).

\begin{tabular}{|c|c|c|c|c|c|c|c|c|c|}
\hline Cultivars & Part & TA & DM & A & VC & $\mathrm{Na}$ & K & $\mathrm{Ca}$ & $P$ \\
\hline \multirow[t]{2}{*}{$\mathrm{BAB}^{*}$} & Pulp & $0.28 \pm 0.04^{\text {bcd }}$ & $13.47 \pm 0.31^{\mathrm{e}}$ & $0.90 \pm 0.03^{b}$ & $2.89 \pm 0.10^{\text {ade }}$ & $7.64 \pm 0.47^{\mathrm{caf}}$ & $206.9 \pm 1.4^{\text {bc }}$ & $20.83 \pm 2.78^{b}$ & $9.29 \pm 0.48^{d}$ \\
\hline & Peel & $0.25 \pm 0.03^{A}$ & $17.70 \pm 0.24 \mathrm{BD}$ & $1.02 \pm 0.04^{\mathrm{BD}}$ & $2.22 \pm 0.06^{\mathrm{D}}$ & $6.71 \pm 0.62^{\mathrm{ACD}}$ & $213.9 \pm 5.6^{\mathrm{ABCD}}$ & $61.11 \pm 1.85^{\circ}$ & $7.62 \pm 0.32^{\mathrm{BDE}}$ \\
\hline \multirow[t]{2}{*}{ BAK $^{*}$} & Pulp & $0.42 \pm 0.04^{\mathrm{ab}}$ & $26.03 \pm 0.09^{d}$ & $0.51 \pm 0.04^{\mathrm{ae}}$ & $2.89 \pm 0.03^{\mathrm{ae}}$ & $6.48 \pm 0.77^{\text {cag }}$ & $254.2 \pm 6.9^{\mathrm{ab}}$ & $28.22 \pm 2.15^{b c}$ & $16.59 \pm 0.53^{\text {ae }}$ \\
\hline & Peel & $0.18 \pm 0.04^{A}$ & $28.69 \pm 0.94^{B}$ & $0.84 \pm 0.07^{\mathrm{AB}}$ & $3.78 \pm 0.09 \mathrm{E}$ & $4.63 \pm 0.31^{\mathrm{AC}}$ & $266.7 \pm 2.8^{\mathrm{ABE}}$ & $125.44 \pm 3.37^{c}$ & $12.06 \pm 0.37^{\mathrm{AC}}$ \\
\hline \multirow[t]{2}{*}{ BID } & Pulp & $0.18 \pm 0.02^{c}$ & $29.33 \pm 0.98^{b}$ & $0.98 \pm 0.05^{b}$ & $8.67 \pm 0.56^{b}$ & $6.25 \pm 0.46^{\mathrm{cd}}$ & $205.6 \pm 8.3^{\mathrm{bc}}$ & $16.67 \pm 2.78^{b}$ & $13.25 \pm 0.27^{\mathrm{ab}}$ \\
\hline & Peel & $0.14 \pm 0.01^{\mathrm{A}}$ & $26.19 \pm 0.07^{\mathrm{A}}$ & $0.82 \pm 0.01^{A}$ & $5.33 \pm 0.22^{\mathrm{B}}$ & $4.40 \pm 0.31^{\mathrm{AC}}$ & $180.6 \pm 2.8^{8 \mathrm{BCF}}$ & $105.11 \pm 4.93^{B}$ & $12.38 \pm 0.48^{c}$ \\
\hline \multirow[t]{2}{*}{$\mathrm{BIT}^{*}$} & Pulp & $0.25 \pm 0.02^{c}$ & $14.41 \pm 0.26^{e}$ & $0.59 \pm 0.01^{a}$ & $2.00 \pm 0.04^{\mathrm{ac}}$ & $14.12 \pm 1.08^{\mathrm{e}}$ & $226.4 \pm 6.9^{b}$ & $22.22 \pm 1.85^{\mathrm{b}}$ & $12.54 \pm 0.53^{\mathrm{ab}}$ \\
\hline & Peel & $0.14 \pm 0.04^{\mathrm{A}}$ & $17.76 \pm 0.03^{D}$ & $0.53 \pm 0.03^{c}$ & $2.89 \pm 0.06^{\mathrm{DF}}$ & $1.62 \pm 0.31^{\mathrm{B}}$ & $165.3 \pm 6.9^{\mathrm{BCF}}$ & $75.00 \pm 5.56^{\mathrm{AD}}$ & $8.73 \pm 0.11^{\mathrm{B}}$ \\
\hline \multirow[t]{2}{*}{ BOG } & Pulp & $0.53 \pm 0.04^{a}$ & $33.28 \pm 0.38^{c}$ & $1.26 \pm 0.01^{c}$ & $2.00 \pm 0.07^{\mathrm{ac}}$ & $9.03 \pm 0.93^{a}$ & $215.3 \pm 1.4^{\mathrm{abc}}$ & $30.56 \pm 3.70^{\text {bcd }}$ & $23.18 \pm 0.42^{c}$ \\
\hline & Peel & $0.25 \pm 0.04^{\mathrm{A}}$ & $29.61 \pm 0.08^{\mathrm{BC}}$ & $0.99 \pm 0.01^{\mathrm{BD}}$ & $1.78 \pm 0.05^{\mathrm{AD}}$ & $7.87 \pm 0.62^{\mathrm{AD}}$ & $244.4 \pm 5.6^{\mathrm{ABE}}$ & $81.94 \pm 4.63^{\mathrm{A}}$ & $11.91 \pm 0.32^{\mathrm{ADC}}$ \\
\hline \multirow[t]{2}{*}{ HAM } & Pulp & $0.53 \pm 0.02^{\mathrm{a}}$ & $24.68 \pm 0.12^{\mathrm{ad}}$ & $0.70 \pm 0.01^{\mathrm{ad}}$ & $1.56 \pm 0.08$ acf & $11.11 \pm 0.93^{\mathrm{ab}}$ & $206.9 \pm 4.2^{\mathrm{bc}}$ & $13.94 \pm 1.93^{\mathrm{ab}}$ & $16.11 \pm 0.53^{\mathrm{ae}}$ \\
\hline & Peel & $0.14 \pm 0.02^{A}$ & $29.94 \pm 0.45^{\mathrm{BC}}$ & $0.97 \pm 0.02^{\mathrm{B}}$ & $1.33 \pm 0.03^{A}$ & $9.03 \pm 0.46^{\mathrm{AD}}$ & $204.2 \pm 4.2^{\mathrm{BCD}}$ & $81.33 \pm 2.89^{A}$ & $10.24 \pm 0.48^{\mathrm{AB}}$ \\
\hline \multirow[t]{2}{*}{$\mathrm{OKH}$} & Pulp & $0.39 \pm 0.03^{b}$ & $24.83 \pm 0.37^{\text {ad }}$ & $0.60 \pm 0.02^{\mathrm{a}}$ & $9.33 \pm 0.52^{b}$ & $7.41 \pm 0.77$ са & $209.7 \pm 6.9 \mathrm{bc}$ & $14.24 \pm 2.39 \mathrm{abc}$ & $14.21 \pm 0.27^{\mathrm{ab}}$ \\
\hline & Peel & $0.21 \pm 0.01^{A}$ & $27.61 \pm 0.49^{A B}$ & $0.79 \pm 0.03^{A}$ & $10.67 \pm 0.31^{c}$ & $4.40 \pm 0.31^{\mathrm{AC}}$ & $187.5 \pm 1.4^{c}$ & $78.89 \pm 2.59^{A}$ & $10.56 \pm 0.21^{\mathrm{AB}}$ \\
\hline \multirow[t]{2}{*}{ SAF } & Pulp & $0.53 \pm 0.01^{a}$ & $23.63 \pm 0,31^{a}$ & $0.63 \pm 0.04^{a}$ & $2.22 \pm 0.07^{\mathrm{a}}$ & $10.65 \pm 0.77^{\mathrm{ab}}$ & $241.7 \pm 5.6^{\mathrm{ab}}$ & $13.89 \pm 1.85^{\mathrm{ab}}$ & $14.79 \pm 0.30^{a}$ \\
\hline & Peel & $0.25 \pm 0.02^{A}$ & $26.07 \pm 0.27^{\mathrm{A}}$ & $0.83 \pm 0.03^{A}$ & $1.33 \pm 0.04^{\mathrm{A}}$ & $6.94 \pm 0.46^{A}$ & $240.3 \pm 4.2^{\mathrm{AB}}$ & $88.89 \pm 4.63^{\mathrm{A}}$ & $9.37 \pm 0.58^{\mathrm{ABD}}$ \\
\hline \multirow[t]{2}{*}{ ZAR } & Pulp & $0.46 \pm 0.02^{\mathrm{ab}}$ & $26.08 \pm 0.44^{d}$ & $0.60 \pm 0.05^{a}$ & $2.44 \pm 0.03^{\text {acde }}$ & $6.94 \pm 0.46^{\mathrm{ca}}$ & $215.3 \pm 4.2^{\mathrm{abc}}$ & $19.06 \pm 2.37^{b}$ & $10.40 \pm 0.42^{d}$ \\
\hline & Peel & $0.25 \pm 0.01^{\mathrm{A}}$ & $31.58 \pm 0.05^{c}$ & $0.85 \pm 0.02^{\mathrm{AB}}$ & $1.56 \pm 0.05^{A D}$ & $4.63 \pm 0.31^{\mathrm{AC}}$ & $181.9 \pm 1.4 \mathrm{BCDF}$ & $121.39 \pm 4.82^{c}$ & $8.18 \pm 0.42^{\mathrm{BD}}$ \\
\hline
\end{tabular}

Abbreviations: BAB: 'Bakkor Biadh', BAK: 'Bakkor Khal', BID: 'Bidha', BIT: 'Bither', BOG: 'Boughandjo', SAF: 'Safra', OKH: 'Onk Elhamam', ZAR: 'Zarrouk'. * Second crop accessions, TA: Titratable acidity (g citric acid equivalents $\left.100 \mathrm{~g}^{-1} \mathrm{FW}\right)$. DM: Dry matter (\%), A: Ash (\%), VC: Vitamin C (mg $100 \mathrm{~g}^{-1} \mathrm{FW}$ ), Na: sodium (mg $100 \mathrm{~g}^{-1} \mathrm{FW}$ ), K: potassium (mg $100 \mathrm{~g}^{-1} \mathrm{FW}$ ), Ca: calcium (mg $100 \mathrm{~g}^{-1} \mathrm{FW}$ ), P: phosphorus (mg $100 \mathrm{~g}^{-1} \mathrm{FW}$ ). Each value represents the mean \pm SEM of 3 measurements. a, b, c, d, ,f,g Mean values of pulps in the same column with different letters are significantly different at $p<0.05$ by mean of the Tukey's multiple comparison test. $A, B, C, D, E, F$ Mean values of peels in the same column with different letters are significantly different at $p<0.05$ by mean of the Tukey's multiple comparison test. 


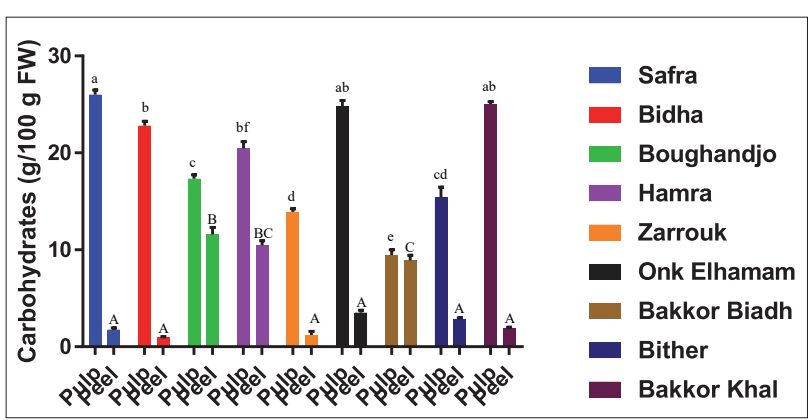

FIGURE 1. Total sugars in pulps and peels of figs (g $100 \mathrm{~g}^{-1}$ FW). (Mean $\pm S E M$ of three measurements). a, b, c, d, e, f Mean values of fruit pulps with various letters correspond to a significant difference at $\mathrm{p}<0.05$ by mean of the Tukey's multiple comparison test. A, B, C Mean values of fruit peels with various letters correspond to a significant difference at $\mathrm{p}<0.05$ by mean of the Tukey's multiple comparison test.

Calcium is another important mineral for health, particularly with regard to maintaining a suitable bone mass. Although dairy products are the principal contributors of calcium intake in humans, its content in fruits should not be ignored (Barea-Álvarez et al., 2016). Our results indicated that fig peel is four-times richer $(\mathrm{p}<0.05)$ in calcium than its pulp

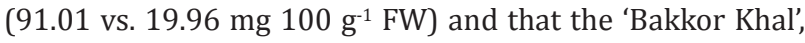
'Zarrouk' and 'Bidha' peels are the richest in calcium among the tested cultivars. According to O'Brien et al. (1998), figs are a very important vegetable resource of calcium.

The mean quantity of sodium and phosphorus in the fig

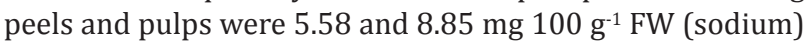

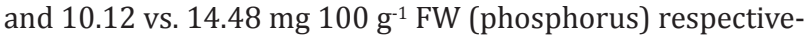
ly. The pulp is the richest fig part in sodium and phosphorus

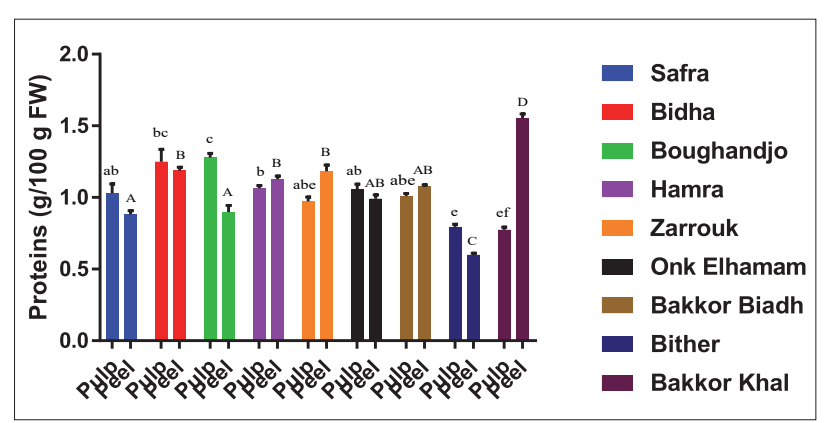

FIGURE 2. Total proteins in pulps and peels of figs (g $100 \mathrm{~g}^{-1}$ FW). (Mean $\pm S E M$ of three measurements). a, b, c, d, e, f Mean values of fruit pulps with various letters correspond to a significant difference at $\mathrm{p}<0.05$ by mean of the Tukey's multiple comparison test. A, B, C, D Mean values of fruit peels with various letters correspond to a significant difference at $\mathrm{p}<0.05$ by mean of the Tukey's multiple comparison test.

$(p<0.05)$. The quantity of sodium of peel and pulp in our study is higher than that of the whole fig fruit (mean: $3 \mathrm{mg}$ $100 \mathrm{~g}^{-1} \mathrm{FW}$ ), where the reverse is true of phosphorus (mean: $23 \mathrm{mg} 100 \mathrm{~g}^{-1} \mathrm{FW}$ ) (Favier et al., 1993).

The concentrations of vitamin $\mathrm{C}$ in pulps and peels of

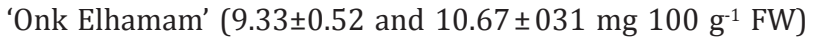

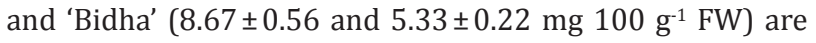
higher $(p<0.05)$ than those of the other cultivars. These concentrations are lower than those recorded by Pande and Akoh (2010) in pulp and peel of the variety 'Brown Turkey'.

According to the data shown in Figure 1, the average content of total sugars of pulp for the nine fig cultivars varied be-

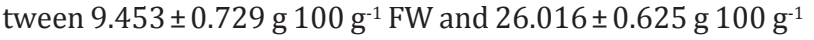
FW, while that of the peel varied between $0.958 \pm 0.118 \mathrm{~g}$

TABLE 6. Extract yield, phytochemical concentrations and antioxidant activity of fig peels and pulps (results of 2016).

\begin{tabular}{|c|c|c|c|c|c|c|c|}
\hline Cultivars & Parts & $Y$ & PC & FC & $A C$ & CTC & $\mathrm{IC}_{50}$ \\
\hline \multirow[t]{2}{*}{$\mathrm{BAB}^{*}$} & Pulp & 14.60 & $0.934 \pm 0.006^{\mathrm{ae}}$ & $102.933 \pm 4.545^{9}$ & $20.618 \pm 0.671^{\mathrm{abf}}$ & $0.824 \pm 0.032^{\text {afe }}$ & $35.028 \pm 0.350^{f}$ \\
\hline & Peel & 14.27 & $2.066 \pm 0.051^{\mathrm{D}}$ & $116.954 \pm 3.359 \mathrm{~F}$ & $0.000 \pm 0.000^{F}$ & $5.674 \pm 0.113^{D}$ & $27.564 \pm 0.365^{c}$ \\
\hline \multirow[t]{2}{*}{ BAK $^{*}$} & Pulp & 22.00 & $0.842 \pm 0.012^{a}$ & $50.980 \pm 3.508^{a}$ & $48.327 \pm 0.240^{e}$ & $1.722 \pm 0.130^{d}$ & $15.870 \pm 0.255^{h}$ \\
\hline & Peel & 18.73 & $3.829 \pm 0.073^{F}$ & $188.896 \pm 1.473^{\mathrm{H}}$ & $159.608 \pm 2.706^{G}$ & $18.468 \pm 0.109^{F}$ & $2.479 \pm 0.044^{F}$ \\
\hline \multirow[t]{2}{*}{ BID } & Pulp & 23.07 & $3.495 \pm 0.016^{b}$ & $37.418 \pm 1.720^{c}$ & $32.242 \pm 1.059^{c}$ & $4.146 \pm 0.087^{b}$ & $24.085 \pm 0.069^{c}$ \\
\hline & Peel & 19.40 & $0.893 \pm 0.009 \mathrm{~B}$ & $161.718 \pm 1.315^{c}$ & $63.481 \pm 1.782^{c}$ & $1.949 \pm 0.069 \mathrm{~B}$ & $31.984 \pm 0.101^{\mathrm{B}}$ \\
\hline \multirow[t]{2}{*}{$\mathrm{BIT}^{*}$} & Pulp & 14.40 & $0.664 \pm 0.010^{c}$ & $104.050 \pm 0.000^{\text {hg }}$ & $54.064 \pm 1.323^{e}$ & $0.607 \pm 0.049 \mathrm{af}$ & $48.772 \pm 0.528^{g}$ \\
\hline & Peel & 11.00 & $0.592 \pm 0.004^{E}$ & $56.753 \pm 1.754^{G}$ & $8.336 \pm 0.505^{F}$ & $0.388 \pm 0.021 E$ & $32.416 \pm 0.091^{B}$ \\
\hline \multirow[t]{2}{*}{ BOG } & Pulp & 21.20 & $0.790 \pm 0.00 \mathrm{~g}^{\mathrm{ad}}$ & $149.456 \pm 4.152^{d}$ & $144.725 \pm 2.827^{d}$ & $1.138 \pm 0.076^{\mathrm{ae}}$ & $36.778 \pm 0.224^{d}$ \\
\hline & Peel & 21.00 & $1.597 \pm 0.012^{A G}$ & $216.067 \pm 1.419 D$ & $65.823 \pm 1.929 c$ & $7.099 \pm 0.038^{A}$ & $27.595 \pm 0.181^{\mathrm{c}}$ \\
\hline \multirow[t]{2}{*}{ HAM } & Pulp & 18.13 & $0.874 \pm 0.010^{\mathrm{a}}$ & $69.487 \pm 1.425^{f e}$ & $19.175 \pm 0.958^{\mathrm{abf}}$ & $1.356 \pm 0.458^{\text {ade }}$ & $31.760 \pm 0.471^{\mathrm{e}}$ \\
\hline & Peel & 15.87 & $0.945 \pm 0.032^{B}$ & $112.429 \pm 0.946^{F}$ & $31.698 \pm 1.457^{\mathrm{E}}$ & $1.658 \pm 0.065^{\mathrm{B}}$ & $17.590 \pm 0.076^{E}$ \\
\hline \multirow[t]{2}{*}{$\mathrm{OKH}$} & Pulp & 17.80 & $0.672 \pm 0.008^{c}$ & $70.550 \pm 2.019 \mathrm{e}$ & $22.072 \pm 1.226^{\mathrm{ab}}$ & $3.275 \pm 0.056^{c}$ & $32.392 \pm 0.241 \mathrm{e}$ \\
\hline & Peel & 17.93 & $1.668 \pm 0.031^{\mathrm{CG}}$ & $254.255 \pm 1.081 \mathrm{E}$ & $109.334 \pm 6.177^{D}$ & $4.630 \pm 0.040^{c}$ & $8.045 \pm 0.145^{D}$ \\
\hline \multirow[t]{2}{*}{ SAF } & Pulp & 17.00 & $0.874 \pm 0.007^{a}$ & $53.302 \pm 4.650^{\mathrm{a}}$ & $22.251 \pm 0.781^{a}$ & $1.052 \pm 0.059^{a}$ & $18.882 \pm 0.009^{a}$ \\
\hline & Peel & 16.20 & $1.520 \pm 0.006^{A}$ & $83.237 \pm 1.002^{A}$ & $17.242 \pm 0.670^{A}$ & $7.329 \pm 0.043^{A}$ & $11.483 \pm 0.101^{\mathrm{A}}$ \\
\hline \multirow[t]{2}{*}{ ZAR } & Pulp & 19.40 & $0.846 \pm 0.009 a$ & $116.210 \pm 3.135^{b}$ & $12.028 \pm 1.336^{b f}$ & $4.420 \pm 0.061^{b}$ & $21.989 \pm 0.154^{b}$ \\
\hline & Peel & 16.80 & $1.557 \pm 0.006^{A}$ & $139.531 \pm 1.169 \mathrm{~B}$ & $127.885 \pm 1.543^{\mathrm{B}}$ & $7.554 \pm 0.133^{A}$ & $11.037 \pm 0.038^{A}$ \\
\hline
\end{tabular}

Abbreviations: BAB: ‘Bakkor Biadh', BAK: ‘Bakkor Khal', BID: 'Bidha', BIT: 'Bither', BOG: 'Boughandjo', SAF: 'Safra', OKH: 'Onk Elhamam', ZAR: 'Zarrouk'. * Second crop accessions, Y: yield (\%), PC: polyphenol concentration (mg GAE g-1 FW), FC: flavonoid concentration ( $\mu \mathrm{g}$ QE g-1 FW), AC: anthocyanin concentration ( $\mu \mathrm{g}$ Cy 3-Rut E g ${ }^{-1} \mathrm{FW}$ ), CTC: condensed tannin concentration $\left(\mu \mathrm{g} \mathrm{CE} \mathrm{g}{ }^{-1} \mathrm{FW}\right) . \mathrm{IC}_{50}\left(\mathrm{mg} \mathrm{mL}^{-1}\right)$ : amount of extract required to scavenge $50 \%$ of radicals present in the reaction mixture. The $\mathrm{IC}_{50}$ values were obtained by linear regression analysis. Each value represents the mean \pm SEM of three measurements. $a, b, c, d, e, f, g, h$ Mean values of pulps in the same column with different letters are significantly different at $p<0.05$ by mean of the Tukey's multiple comparison test. $A, B, C, D, E, F, G, H$ Mean values of peels in the same column with different letters are significantly different at $p<0.05$ by mean of the Tukey's multiple comparison test. 


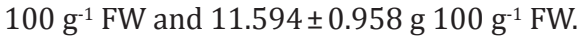

For all the studied cultivars, the pulp is four times sweet-

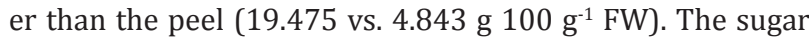
composition of fig fruit can influence perceived fruit sweetness. The perception of sweetness in fig accessions is likely due to the prevalence of fructose (Çaliskan and Polat, 2011).

The concentrations of proteins in the pulps and the peels of figs (Figure 2) varied between $0.773 \pm 0.023$ and

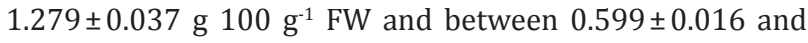

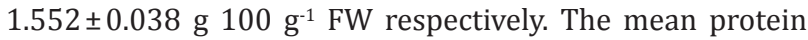
concentration of the fig peel is slightly higher $(p>0.05)$ than

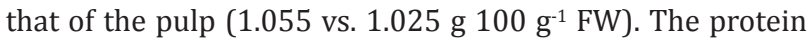

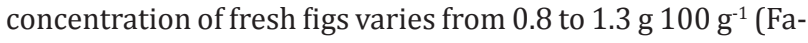
vier et al., 1993).

\section{Phytochemical characteristics}

The peel of 'Bakkor Khal' and pulp of 'Bidha' were richest in polyphenols $(3.829 \pm 0.073$ and $3.495 \pm 0.016 \mathrm{mg} \mathrm{GAE}$ $\mathrm{g}^{-1} \mathrm{FW}$ ) and those of 'Bither' register the lowest concentrations $\left(0.592 \pm 0.004\right.$ (peel) and $0.664 \pm 0.01$ (pulp) mg GAE g $\left.{ }^{-1} \mathrm{FW}\right)$ (Table 6). The peel of 'Onk Elhamam' and pulp of 'Boughand- jo' had the highest levels of flavonoids $(254.255 \pm 1.081$ and $149.456 \pm 4.152 \mu \mathrm{g} \mathrm{QE} \mathrm{g}{ }^{-1} \mathrm{FW}$ ) whereas those of 'Bither' and 'Bidha' had the lowest amounts. The total anthocyanin amount ranged from $0.00 \pm 0.00$ to $159.608 \pm 2.706 \mu \mathrm{g} \mathrm{C}-3-\mathrm{RE}$ $\mathrm{g}^{-1} \mathrm{FW}$ for peels and from $12.028 \pm 1.336$ to $144.725 \pm 2.827$ $\mu \mathrm{g} \mathrm{C}-3-\mathrm{RE} \mathrm{g}^{-1} \mathrm{FW}$ for pulps. The concentrations of condensed tannins in the peel of 'Bakkor Khal' and the pulp of 'Zarrouk' were the highest $(18.468 \pm 0.109$ and $4.420 \pm 0.061 \mu \mathrm{g} \mathrm{CE}$ $\left.\mathrm{g}^{-1} \mathrm{FW}\right)$ while in those of 'Bither' are the lowest $(0.388 \pm 0.021$ and $0.607 \pm 0.049 \mu \mathrm{g} \mathrm{CE} \mathrm{g}^{-1} \mathrm{FW}$ ).

In general, fig pulps had a higher mean yield than their peels (18.62 vs. 16.8\%). Whereas, fig peels had higher $(\mathrm{p}<0.05)$ mean quantities of polyphenols, flavonoids, anthocyanins, and condensed tannins than the pulps (1.63 vs. $1.11 \mathrm{mg} \mathrm{GAE} \mathrm{g}^{-1} \mathrm{FW} ; 147.760$ vs. $83.821 \mu \mathrm{g} \mathrm{QE} \mathrm{g}^{-1} \mathrm{FW}$; 64.823 vs. $41.722 \mu \mathrm{g} \mathrm{C}-3-\mathrm{R} \mathrm{E} \mathrm{g}^{-1} \mathrm{FW}$; and 6.083 vs. $2.060 \mu \mathrm{g}$ $\mathrm{CE} \mathrm{g}^{-1} \mathrm{FW}$ ).

In this study, peels of all fig cultivars, except 'Bidha' and 'Bither' (green varieties), had a higher phenolic concentration than its pulps. This is in agreement with Vallejo et al. (2012) and Oliveira et al. (2009), who found that fig peel had

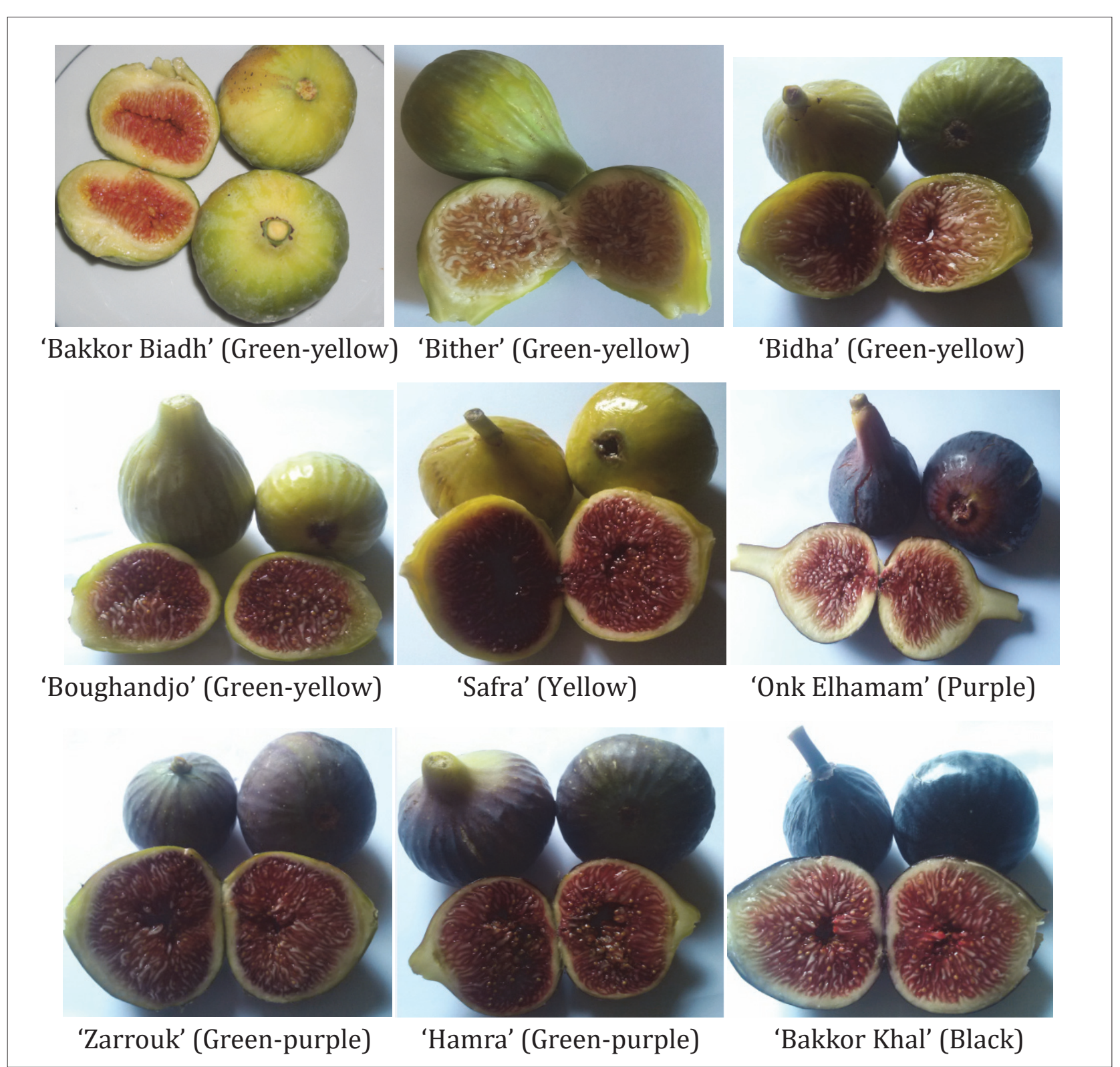

FIGURE S1. Photographs of the studied fig cultivars (Original, 2015). 
a higher phenolic concentration than its pulp, and with Harzallah et al. (2016) and Solomon et al. (2006), who reported that total phenolic concentrations of 'Bidhi' and 'Kadota' pulps (green varieties) were higher compared with peels.

Flavonoid concentration, in our study, was significantly $(\mathrm{p}<0.05)$ higher in peels than in pulps (except in 'Bither'). Several other authors (Viuda-Martos et al., 2015; Harzallah et al., 2016) have reported similar. Phenolic acids and flavonoids (3-O- and 5-O-caffeoylquinic acids, ferulic acid, quercetin-3-O-glucoside, quercetin-3-O-rutinoside, psoralen, and bergapten) have been previously isolated from the pulps and peels of two Portuguese varieties of fig (Oliveira et al., 2009).

The anthocyanin concentrations registered in our study were higher than those reported by Duenas et al. (2008), but were much lower than those mentioned by Harzallah et al. (2016) and Viuda-Martos et al. (2015). Those authors also found that the fig peel had a higher amount of anthocyanin than the pulp. Fifteen anthocyanin pigments have been isolated from the peels and pulps of fresh figs. Cyanidin 3-rutinoside was the predominant component in fig fruit, followed by the Cyanidin 3-glucoside (Duenas et al., 2008).

For the light-skinned figs, pulps showed higher mean phenolic, flavonoid, and anthocyanin concentrations than those of dark skin figs (1.351 vs. $0.808 \mathrm{mg} \mathrm{GAE} \mathrm{g}^{-1} \mathrm{FW}$; 89.430 vs. $76.810 \mu \mathrm{g} \mathrm{QE} \mathrm{g}^{-1} \mathrm{FW}$ and 54.78 vs. $25.4 \mu \mathrm{g} \mathrm{C-3-RE}$ $\left.\mathrm{g}^{-1} \mathrm{FW}\right)$. While peels of dark cultivars showed higher mean phytochemical amounts than those of light cultivars $(2.000$ vs. $1.334 \mathrm{mg} \mathrm{GAE} \mathrm{g}^{-1} \mathrm{FW} ; 173.8$ vs. $126.9 \mu \mathrm{gE} \mathrm{g}^{-1} \mathrm{FW} ; 107.1$ vs. $30.98 \mu \mathrm{g} \mathrm{C-3-RE} \mathrm{g}{ }^{-1} \mathrm{FW}$; and 8.077 vs. $4.488 \mu \mathrm{g} \mathrm{CE} \mathrm{g}^{-1} \mathrm{FW}$ ).

Several authors (Solomon et al., 2006; Çaliskan and Polat, 2011; Harzallah et al., 2016) have previously reported that dark-skinned figs have a higher phenolic level than lightskinned figs.

We found that the peel and the pulp of 'Bakkor Khal' exhibited the highest antioxidant activity (Table 6), whereas the peel and pulp of the 'Bither' variety had the lowest antioxidant activity. Except for 'Bidha', the fruit peel had a higher mean antioxidant activity than the pulp (IC50 $=18.910$ vs. $\left.29.506 \mathrm{mg} \mathrm{mL}^{-1}, \mathrm{p}<0.05\right)$. Oliveira et al. (2009), in their study on two Portuguese varieties ('Pingo de Mel' and 'Branca Tradicional') also found that the peels were more effective as an antioxidant than pulps.

The peels and pulps of the dark-skinned group had a lower mean IC50 than the light skinned group (9.788 vs. 25.503 $\mathrm{mg} \mathrm{mL}{ }^{-1}$ ), indicating that dark-skinned cultivars are most effective as an antioxidant than the light skinned cultivars. Solomon et al. (2006) and Crisosto et al. (2010) found that fig varieties with dark skin contain higher levels of polyphenols, anthocyanins, and flavonoids than lighter skin types and that this is associated with higher antioxidant activity. The cultivar is the most important variable influencing the phytochemical composition of figs (Yeh et al., 2003).

We found that the fig phenolic concentration is well correlated with condensed tannin amount $(r=0.779)$ but only moderately correlated with yield extract and flavonoid and anthocyanin concentrations. We detected a strong correlation between anthocyanin amount and flavonoid and tannin levels ( $\mathrm{r}=0.656$ and $\mathrm{r}=0.519$ respectively) (Supplementary Table S1). The IC50 was negatively correlated with the condensed tannin and phenolic concentration. This means that the antioxidant activity of fig peels and pulps is dependent on tannin and phenolic concentrations.

Luminosity ( $\mathrm{L}^{*}$ ) values were positively correlated with anthocyanin content $(\mathrm{r}=0.595)$ and moderately correlated with other parameters. We detected a strong correlation ( $\mathrm{r}=0.979)$ between the Chroma ( $\mathrm{C}^{*}$ ) values and luminosity values.

\section{Conclusion}

Here we describe the important pomological traits of fresh fig cultivars, including fruit length and diameter, fruit weight, fruit skin and pulp color, fruit neck length, and fruit shape. Consumer acceptance of fresh figs was significantly affected by ease of peeling, pulp flavor, juiciness, sweetness, and acidity. Among the tested cultivars, fruits of 'Boughandjo', 'Bither' and 'Bakkor Biadh' were the most accepted for the fresh consumption.

We found that the peels and pulps of fig have good nutritional value. The fruit pulps are rich in carbohydrates and the peel of the 'Onk Elhamam' cultivar had the highest vitamin C content. Of the tested varieties, the pulp of the 'Boughandjo' cultivar contained the highest concentration of phosphorus and the peel of the 'Bakkor Khal' cultivar was richest in potassium and calcium.

The peels and pulps of the tested cultivars had variable levels of polyphenols, flavonoids, anthocyanins, tannins, and antioxidant activity. Generally, fig fruit peels, especially those with a dark color, contained the highest concentrations of phytochemicals and exhibited the highest antioxidant activity compared to fig fruit pulps. Based on our mineral and phytochemical analyses, we recommend consumption of the whole fig fruit.

\section{Acknowledgments}

This work was financed by the Algerian Ministry of Higher Education and Scientific Research.

\section{References}

AFNOR NEV 03-050 (1970) in AFNOR (1991). Recueil des normes françaises, contrôle de la qualité des produits alimentaires, céréales et produits céréaliers. AFNOR/DGCCRF, 3 ème éd. (Paris), 360 pp.

AFNOR. (1982). Recueil de normes françaises des produits dérivés des fruits et légumes, jus de fruits. 325 pp.

Ba, K., Tine, E., Destain, J., Cisse, N., and Thonart P. (2010). Étude comparative des composés phénoliques, du pouvoir antioxydant de différentes variétés de sorgho sénégalais et des enzymes amylolytiques de leur malt. Biotechnol. Agron. Soc. Environ. 14, 131-139.

Barea-Álvarez, M., Delgado-Andrade, C., Haro, A., Olalla, M., Seiquer, I., and Rufián-Henares, J.Á. (2016). Subtropical fruits grown in Spain and elsewhere: A comparison of mineral profiles. J. Food Comp. and Anal. 48, 34-40. https://doi.org/10.1016/j.jfca.2016.02.001.

Çaliskan, O., and Polat, A. (2008). Fruit characteristics of fig cultivars and genotypes grown in Turkey. Sci. Hortic. 115, 360-367. https:// doi.org/10.1016/j.scienta.2007.10.017.

Caliskan, O., and Polat, A. (2011). Phytochemical and antioxidant properties of selected fig (Ficus carica L.) accessions from the eastern Mediterranean region of Turkey. Sci. Hortic. 128, 473-478. https://doi.org/10.1016/j.scienta.2011.02.023.

Chouaki, S. (2006). Deuxième Rapport National sur l'État des Ressources Phytogénétiques (INRAA), 91 pp.

Crisosto, C.H., Bremer, V., Ferguson, L., and Crisosto, G.M. (2010). Evaluating quality attributes of four fresh fig (Ficus carica L.) cultivars harvested at two maturity stages. HortScience 45, 707-710.

Dubois, M., Gilles, K.A., Hamilton, J.K., Rebers, P.A., and Smith, F. (1956). Colorimetric method for determination of sugar and related substances. Anal. Chem. 28, 350-356. https://doi.org/10.1021/ ac60111a017. 
Duenas, M., Pérez-Alonso, J., Santos-Buelga, C., and EscribanoBailon, T. (2008). Anthocyanin composition in fig (Ficus carica L.). J. Food Comp. Anal. 21, 107-115. https://doi.org/10.1016/j. jfca.2007.09.002

FAOStat. (2016). FAO statistics database on the World Wide Web, 2016. http://apps.fao.org/.

Favier, J.C., Ireland-Ripert, J., Laussucq, C., and Feinberg, M. (1993) Répertoire générale des aliments. Table de composition des fruits exotiques, fruits de cueillette d'Afrique, Tome 3. (France: Tech. \& Doc., CIQUAL-CNEVA), 207 pp.

Fu, L., Xu, B.T., Xu, X.R., Gan, R.Y., Zhang, Y., Xia, E.Q., and Li, H.B. (2011). Antioxidant capacities and total phenolic contents of 62 fruits. Food Chem. 129, 345-350. https://doi.org/10.1016/j. foodchem.2011.04.079.

Harzallah, A., Mnari Bhouri, A., Amri, Z., Soltana, H., and Hammami, M. (2016). Phytochemical content and antioxidant activity of different fruit parts juices of three figs (Ficus carica L.) varieties grown in Tunisia. Ind. Crops Prod. 83, 255-267. https://doi.org/10.1016/j. ind crop.2015.12.043.

Hatano, K.I., Kubota, K., and Tanokura, M. (2008). Investigation of chemical structure of nonprotein proteinase inhibitors from dried figs. Food Chem. 107, 305-311. https://doi.org/10.1016/j. foodchem.2007.08.029.

Hendry, G.A.F., and Houghton, J.D. (1996). Natural Food Colorants (Glasgow, Scotland: Blackie Academic and Professional), 348 pp. https://doi.org/10.1007/978-1-4615-2155-6.

Ilgin, M. (1995). The investigation of fertilization biology of some fig genotypes selected from Kahramanmaras region. (Ph.D. thesis) (Adana, Turkey: Çukurova University).

IPGRI and CIHEAM. (2003). Descriptors for Fig (Rome, Italy: International Plant Genetic Resources Institute; Paris, France: International Centre for Advanced Mediterranean Agronomic Studies). http://www.ipgri.cgiar.org/.

Koh, P.H., Mokhtar, R.A., and Iqbal, M. (2012). Antioxidant potential of Cymbopogon citrates extract: alleviation of carbon tetrachlorideinduced hepatic oxidative stress and toxicity. Hum. Exp. Toxicol. 31, 81-91. https://doi.org/10.1177/0960327111407226.

Koolen, H.F., Da Silva, M.A., Gozzo, C., De Souza, Q.L., and De Souza, A.D.L. (2013). Antioxidant, antimicrobial activities and characterization of phenolic compounds from buriti (Mauritia flexuosa L. f.) by UPLC-ESI-MS/MS. Food Res. Int. 51, 467-473. https://doi.org/10.1016/j.foodres.2013.01.039.

Lee, J., Durst, R.W., and Wrolstad, R.E. (2005). Determination of total monomeric anthocyanin pigment content of fruit juices, beverages, natural colorants, and wines by the $\mathrm{pH}$ differential method: Collaborative study. J. AOAC Int. 88, 1269-1278.

MADR. (2012). Ministry of Agriculture and Rural Development. Service of the Statistics (Algiers, Algeria).

Meziant, L., Saci, F., Bachir Bey, M., and Louaileche, H. (2015). Varietal influence on biological properties of Algerian light figs (Ficus carica L.). Int. J. Bioinform. Biomed. Eng. 1, 237-243.

O’Brien, T.G., Kinnaird, M.F., Dierenfeld, E.S., Conklin-Brittain, N.L. Wrangham R.W., and Silver, S.C. (1998). What's so special about figs? Nature 392, 668. https://doi.org/10.1038/33580.

Oliveira, A.P., Valentão, P., Pereira, J.A., Silva, B.M., Tavares, F., and Andrade, P.B. (2009). Ficus carica L.: Metabolic and biological screening. Food Chem. Tox. 47, 2841-2846. https://doi. org/10.1016/j.fct.2009.09.004.

Pande, G., and Akoh, C.C. (2010). Organic acids, antioxidant capacity, phenolic content and lipid characterization of Georgia-grown underutilized fruit crops. Food Chem. 120, 1067-1075. https://doi. org/10.1016/j.foodchem.2009.11.054
Polat, A., and Çaliskan, O. (2008). Fruit characteristics of table fig (Ficus carica) cultivars in subtropical climate conditions of the Mediterranean region. N. Z. J. Crop and Hortic. Sci. 36, 107-115 https://doi.org/10.1080/01140670809510226.

Sadia, H., Ahmad, M., Sultana, S., Abdullah, A.Z., Keat Teong, L., Zafar, M., and Bano, A. (2014). Nutrient and mineral assessment of edible wild fig and mulberry fruits. Fruits 69, 159-166. https://doi. org/10.1051/fruits/2014006

Sen, F., Meyvaci, K.B., Aksoy, U., and Cakir, M. (2008). Studies to optimize pre-treatments for high moisture dried figs. Acta Hortic. 798, 293-297. https://doi.org/10.17660/ActaHortic.2008.798.42.

Slavin, J.L. (2006). Figs: Past, Present and Future. Nutr. Today 41, 180-184. https://doi.org/10.1097/00017285-200607000-00009.

Solomon, A., Golubowicz, S., Yablowicz, Z., Grossman, S., Bergman, M., Gottlieb, H.E., Altman, A., Kerem, Z., and Flaishman, M.A. (2006) Antioxidant activities and anthocyanin content of fresh fruits of common fig (Ficus carica L.). J. Agri. Food Chem. 54, 7717-7723. https://doi.org/10.1021/jf060497h.

Tareen, H., Ahmed, S., Mengal, F., Masood, Z., Bibi, S., Mengal, R., Shoaib, S., Irum, U., Akbar, S., Mandokhail, F., and Taj, R. (2015). Estimation of vitamin $C$ content in artificially packed juices of two commercially attracted companies in relation to their significance for human health. Biol. Forum 7, 682-685.

Trad, M., Gaaliche, B., Renard, C.M.G.C., and Mars, M. (2012). Quality performance of 'Smyrna' type figs grown under Mediterranean conditions of Tunisia. J. Ornam. and Hortic. Plants 2, 139-146.

Travers, S. (2013). Dry matter and fruit quality: manipulation in the field and evaluation with NIR spectroscopy. (Ph.D. thesis) (Denmark: Aarhus University), 283 pp.

Veberic, R., Colaric, M., and Stampar, F. (2008). Phenolic acids and flavonoids of fig fruit (Ficus carica L.) in the northern Mediterranean region. Food Chem. 106, 153-157. https://doi.org/10.1016/j. foodchem.2007.05.061.

Viuda-Martos, M., Barber, X., Pérez-Álvarez, J.A., and FernándezLópez, J. (2015). Assessment of chemical, physico-chemical, techno-functional and antioxidant properties of fig (Ficus carica L.) powder co-products. Ind. Crops and Prod. 69, 472-479. https://doi. org/10.1016/j.indcrop.2015.03.005

Yeh, G.Y., Eisenberg, D.M., Kaptchuk, T.J., and Phillips, R.S. (2003). Systematic review of herbs and dietary supplements for glycemic control in diabetes. Diabetes Care 26, 1277-1294. https://doi. org/10.2337/diacare.26.4.1277.

Youshida, S., Forno, D., Cock, J., and Gomez, K. (1976). Laboratory manual for physiological studies of rice. (Philippines: The International Rice Research Institute), 82 pp.

Received: Apr. 4, 2017

Accepted: Jul. 21, 2017

Addresses of authors:

S. Mahmoudi ${ }^{1,2, *}$, M. Khali ${ }^{2}$, A. Benkhaled ${ }^{3}$, I. Boucetta ${ }^{1}$,

Y. Dahmani ${ }^{3}$, Z. Attallah ${ }^{3}$ and S. Belbraouet ${ }^{4}$

${ }^{1}$ Department of Agronomic Sciences, University "Med

Boudiaf”, PB 166, M'sila 28000, Algeria

2 Department of Food Sciences, University "Saâd Dahleb”, PB 270, Blida 9000, Algeria

${ }^{3}$ Department of Microbiology and Biochemistry, University

"Med Boudiaf", PB 166, M'sila 28000, Algeria

${ }^{4}$ Faculty of Health Sciences and Community Services,

University of Moncton, Canada

* Corresponding author 